ISSN : 1412 - 8837

\title{
AGRIBISNIS PERKEBUNAN RAKYAT KOPI ROBUSTA DI KABUPATEN SOLOK
}

\author{
Smallholder Agribussiness of Robusta Cofee in Solok District
}

\author{
Rika Hariance, Rudi Febriamansyah, dan Faidil Tanjung \\ Jurusan Sosial Ekonomi Pertanian Fakultas Pertanian Universitas Andalas \\ email : rikahariance@gmail.com, rudifeb@yahoo.com, faidilt@yahoo.com
}

\begin{abstract}
The largest area of local coffee plantation in West Sumatera Province is in the District of Solok, that covers the area around 9,300 $\mathrm{Ha}$, with the annual production of 8,500 Ton. There are two varieties of coffee in this District, arabica and robusta. The area of robusta coffee is around 7,700 $\mathrm{Ha}$ that are much larger than arabica of 1,600 Ha. Although the price of arabica coffee is much higher than robusta, farmers prefer to cultivate robusta coffee mainly due to its resistance to plant diseases, low maintenance cost and higher demand compare to arabica coffee. Since the Robusta coffee is the second largest of local plantation after casiavera in Solok. There is a need for the district government to get a suitable development not only for the benefit of local farmers but also for regional development of Solok district itself. This study applied descriptif qualitative method to analyze the interrelationship of agribusiness sub-systems and its potential aspect. The results shows that the interrelationship of four subsystems of the agribusiness of Robusta coffee agribusiness were not strong enough to face the influences from the external factors of the systems. This, then guided the recommendation to improve the competitiveness of the Robusta coffee, mainly by increasing the quality and appearance of its market form and its dairy products.

Keywords: Robusta coffee, Solok-West Sumatera, Potential Aspect
\end{abstract}

\section{PENDAHULUAN}

Sebagai bagian dari pembangunan daerah maka secara umum pembangunan sektor pertanian harus diarahkan kepada pendekatan pembangunan berbasis kerakyatan (Ahmad, 2006). Berbagai hasil pembangunan terutam a yang berkaitan dengan upaya pemberdayaan masyarakat perkebunan, umumnya mempunyai margin pendapatan yang besar, yang lebih banyak dinikmati oleh pengusaha besar, belum banyak dinikmati oleh petani. Karena Petani hanya menikmati pendapatan produksi (on farm) saja (Admaizon, 2004). Subsektor perkebunan merupakan salah satu bisnis strategis dan andalan dalam perekonomian Indonesia, bahkan pada masa krisis ekonomi. 
Agribisnis subsektor ini mempunyai kontribusi yang signifikan terhadap stabilitas ekonomi makro, pertumbuhan, penciptaan lapangan kerja, penerimaan devisa dari ekspor, dan sumber bahan baku bagi industri hilir hasil pertanian. (Susila dan Drajat, 2009).

Kopi hingga saat ini masih merupakan salah satu komoditi hasil perkebunan yang penting dalam perekonomian Nasional. Kopi yang dimaksud disini adalah kopi robusta, dari total produksi kopi Indonesia 90\% nya adalah kopi robusta dan $10 \%$ kopi arabika. Dari jumlah kopi yang diperdagangkan di pasar internasional 70\% nya adalah kopi robusta, dan 30\% kopi Arabika (Kustari, 2007).

Kopi merupakan salah satu komoditas andalan perkebunan yang mempunyai kontribusi cukup nyata dalam perekonomian Indonesia, yaitu sebagai penghasil devisa, sumber pendapatan petani, penghasil bahan baku industri, penciptaan lapangan kerja dan pengembangan wilayah (Sutriono, 2009). Di Indonesia tanaman kopi tersebar diseluruh provinsi kecuali DKI Jakarta. Khusus di Sumatera Barat bila dibandingkan dengan tanaman ekspor lainnya kopi merupakan komoditi keempat setelah kelapa sawit, karet dan casiavera. Nilai ekspor kopi Sumbar ${ }^{1}$ pada tahun 2008 adalah sebesar 659,40 ton mengalami peningkatan sebesar 106,9 ton dibandingkan dengan tahun 2007 yaitu sebesar 552, 5 ton yang diproduksi diatas lahan seluas 46.890 Ha yang tersebar diseluruh Kabupaten dan Kota (BPS, 2009).

Kabupaten Solok Merupakan wilayah paling luas yang mengusahakan kopi di Sumatera Barat. Pada tahun 2009 luas lahan kopi di kabupaten solok adalah seluas $9.296,75$ ha dengan jumlah produksi sebesar $8.404,6$ ton/ha. (Statistik Perkebunan Kab. Solok, 2009). Menurut informasi yang diperoleh dari Dinas Perkebunan dan Kehutanan Kabupaten Solok potensi lahan yang dapat dikembangkan untuk kebun kopi robusta adalah sebanyak 8. 263, $95 \mathrm{Ha}$, namun yang dapat termanfaatkan hanya seluas 7.700,60 Ha, sehingga masih tersisa 563,35 Ha areal yang akan dikembangkan untuk agribisnis kopi robusta ini, baik sebagai lahan kebun, pembibitan, maupun untuk pengolahan pasca panen.

Pengembangan Agribisnis membutuhkan keterlibatan semua subsistem yang ada dalam sistem agribisnis tersebut, yaitu berupa subsistem penyedia saprodi, produksi (on farm), sistem pengolahan, sistem pemasaran maupun sistem penunjang berupa lembaga keuangan maupun lembaga penelitian.

1 Berdasarkan Data Badan Pusat Statistik (BPS) Sumbar menunjukkan nilai ekspor Sumbar tahun 2013 hanya US\$ 2.2 miliar, atau mengalami penurunan 6,54\% dari tahun sebelumnya yang mencapai US\$ 2.3 miliar. Nilai ekspor kopi, teh, dan komoditi rempah-rempah 47,13\% yaitu senilai US\$ 20 juta (BPS, 2014). 
Dari latar belakang dan perumusan masalah diatas, maka perlu diketahui bagaimanakah aspek potensial sistem agribisnis kopi robusta yang merupakan perkebunan rakyat di Kabupaten Solok?. Berdasarkan perumusan masalah diatas dirasa perlu untuk melakukan penelitian tentang Agribisnis Perkebunan Rakyat Kopi Robusta di Kabupaten Solok ${ }^{1}$. Adapun tujuan dari penelitian ini adalah menganalisa sistem agribisnis kopi robusta di Kabupaten Solok dan menganalisis aspek potensi agribisnis kopi robusta di Kabupaten Solok

\section{METODOLOGI PENELITIAN}

\section{Waktu dan Lokasi Penelitian}

Pelaksanaan penelitian ini dilakukan di Kabupaten Solok. Pemilihan lokasi dilakukan secara purposive (sengaja) pada Kecamatan Pantai Cermin, Tigo Lurah dan X Koto Singkarak.

\section{Populasi dan Sampel}

Jumlah petani yang mengusahakan kopi robusta di Kabupaten Solok adalah sebanyak 6.910 orang. Untuk wilayah Kec. Pantai Cermin, Tigo Lurah dan X Koto Singkarak jumlah petani yang mengusahakan adalah 1.735 orang petani. Sampel diambil sebanyak $5 \%$ dari jumlah tersebut sehingga jumlah sampel adalah 86 orang. Kemudian di lakukan pengambilan sampel secara proposional, maka kec. Pantai Cermin diambil sebanyak 39 orang sampel, Tigo Lurah sebanyak 19 Orang sampel dan X koto Singkarak sebanyak 28 Orang sampel.

\section{Sumber Data dan Teknik Pengumpulan Data}

Data yang dikumpulkan dalam penelitian ini terdiri dari data primer dan data sekunder. Data primer diperoleh dari sumbernya (responden) melalui wawancara dengan menggunakan daftar pertanyaan dan melakukan pengamatan langsung dilapangan. Data sekunder adalah data yang digunakan untuk penunjang data primer dalam penelitian, yang dikumpulkan dari instansi/lembaga terkait dan pihak-pihak yang ada relevansinya dengan penelitian ini. Untuk menganalisa sistem agribisnis kopi robusta Kabupaten Solok, data primer yang akan dikumpulkan meliputi : identitas petani sampel, teknik budidaya, pengadaan faktor produksi, pemasaran, pengolahan hasil dan lembaga penunjang yang terlibat dalam system agribisnis kopi robusta. Data Sekunder meliputi : gambaran umum daerah penelitian, kondisi ekonomi (mata pencaharian), kondisi Sosial ekonomi (jumlah penduduk dan pendidikan) . 


\section{Variabel Yang diamati}

Untuk menganalisa sistem agribisnis kopi robusta di Kabupaten Solok maka variabel yang diamati adalah:

a. Penyediaan sarana dan prasaran produksi

b. Kondisi usahatani kopi robusta

c. Kondisi pengolahan pascapanen

d. Kondisi pemasaran

e. Faktor penunjang yang tersedia dalam agribisnis kopi robusta di Kabupaten Solok

Untuk menganalisa aspek potensi agribisnis kopi robusta di Kabupaten Solok diperoleh dari data yang telah didapatkan pada tujuan pertama.

\section{Metode Analisis Data}

Metode yang digunakan adalah analisa deskriptif kualitatif dengan menggambarkan kondisi agribisnis kopi robusta di Kabupaten Solok dan aspek potensialnya.

\section{HASIL DAN PEMBAHASAN}

\section{Gambaran Umum Daerah Penelitian}

\section{Kondisi Fisik dan Sosial Ekonomi}

Kabupaten Solok memiliki topografi daerah yang bervariasi antara dataran, lembah dan bukit-bukit dengan ketinggian $329 \mathrm{~m}-1.458 \mathrm{~m}$ dpl. Berbatasan dengan Kab. Solok Selatan di Sebelah Selatan, Kab. Tanah datar di sebelah utara, Kota Padang di sebelah barat dan kab. Sawah lunto di sebelah timur. Kabupaten Solok terletak pada jalur strategis karena berada di jalur lintas sumatera dan berbatasn dengan kota padang serta memiliki dua buah danau yang terkenal.

Luas lahan yang digunakan untuk tanaman perkebunan rakyat adalah seluas 36.953 Ha dan 20,83 \% diusahakan untuk tanaman perkebunan kopi robusta yaitu seluas 7.700, 60 Ha. Kabupaten Solok merupakan wilayah beriklim tropis. Secara umum Kabupaten Solok beriklim tropis dengan temperatur berada pada kisaran $12-32{ }^{\circ} \mathrm{C}$, kelembaban udara mencapai $80 \%$ dan curah hujan sebanyak 268,93 mm/th, sedangkan kecepatan angin mencapai 0,67 Knot. Kabupaten Solok berada pada ketinggian tempat 329 - 1.458 meter diatas permukaan laut (Profil Kab. Solok, 2007). Kondisi iklim yang seperti ini merupakan iklim yang cocok untuk tanaman kopi robusta. Karena tanaman ini dapat tumbuh pada suhu $21-24{ }^{\circ} \mathrm{C}$ dan ketinggian tempat $400-800 \mathrm{mdpl}$ (Retnandari, 1991).

Sektor pertanian memberikan kontribusi yang besar terhadap PDRB Kab. Solok yaitu sebesar $45,14 \%$ termasuk didalamnya sektor perkebunan. Sektor pertanian termasuk perkebunan robusta masih merupakan sektor yang 
diusahakan oleh rakyat dalam skala kecil, ketergantungan yang besar tetrhadap sektor ini dalam jangka panjang akan berdampak dalam kesejahteraan masyarakat. Untuk itu diperlukan upaya meningkatkan sektor industri pengolahan agar dapat meningkatkan serapan tenaga kerja diluar sektor pertanian yang berdampak pada peningkatan kesejahteraan masyarakat.

Kabupaten Solok memiliki 14 kecamatan dan hanya 2 kecamatan yang tidak mengusahakan kopi robusta yaitu Kec. Lembah gumanti dan Danau Kembar yang mengusahakan kopi arabika.

Wilayah paling padat penduduk di Kabupaten Solok adalah Kecamatan Kubung dan yang paling rendah adalah Kecamatan Tigo Lurah. Berkaitan dengan wilayah penelitian maka ketiga kecamatan yang menjadi wilayah penelitian merupakan wilayah yang kepadatan penduduknya rendah sehingga lahan yang tersedia cukup luas untuk aktivitas pertanian dan perkebunan.

Mata pencaharian masyarakat Kabupaten Solok pada umumnya adalah pertanian $(71,68 \%)$. Dari jumlah penduduk yang bekerja pada sektor pertanian tersebut sebanyak $14.740 \mathrm{KK}$ petani atau $15,91 \%$ nya bekerja pada sektor perkebunan kopi robusta (Dinas Kehutanan dan Perkebunan Kab. Solok, 2008).

\section{Keadaan perkebunan}

Pada subsektor perkebunan jenis tanaman yang potensial di Kabupaten Solok antara lain teh, kopi, coklat (kakao), karet dan cengkeh. Komoditas yang telah dikelola oleh perkebunan besar adalah teh, kopi dan kakao. Sentra perkebunan kopi robusta adalah Kecamatan Pantai Cermin, Tigo Lurah dan X Koto Singkarak yang diusahakan secara perkebunan rakyat. Kondisi daerah yang berbukit dari dataran sedang dan tinggi merupakan daerah yang sangat potensial untuk diversifikasi usaha dengan komoditas kopi. Kabupaten Solok memiliki 213 kios saprodi sebagai penyedia sarana produksi pertanian dan 14 pasar mingguan serta 1 pasar harian sebagai sarana pemasaran. Seperti yang terlihat pada tabel dibawah ini.

Tabel 1. Data Prasarana dan Kelembagaan Pertanian di Kabupaten Solok.

\begin{tabular}{llc}
\hline o & Prasarana/ Kelembagaan Pertanian & Jumlah \\
\hline & Bank Milik Pemerintah Dan Swasta & 8 \\
Bank Perkreditan Rakyat (BPR) & 4 \\
Koperasi Unit Desa (KUD) & 4 \\
Koperasi Non KUD & 30 \\
Kios Saprodi & 213 \\
Lembaga Penelitian & 1 \\
Pasar & 15 \\
UMKM & 350 \\
\hline
\end{tabular}

Sumber :Profil Kabupaten Solok, 2007; RIPP Kabupaten Solok, 2008 


\section{Analisa sistem Agribisnis Kopi robusta di Kab. Solok Subsistem Hulu}

Kegiatan yang terdapat di subsistem ini adalah kegiatan yang menghasilkan dan memperdagangkan sarana dan prasaran produksi pertanian primer. $88,37 \%$ petani kopi robusta tidak memanfaatkan sarana kios saprodi yang ada, karena petani dalam usahataninya tidak melakukan budidaya dengan intensif. Bibit yang digunakan untuk pergantian tanaman adalah bibit yang berasal dari kebun sendiri, tanpa ada perlakuan khusus untuk pembibitan. Sarana produksi pertama adalah bibit, kelemahan pada proses penyediaan bibit terdapat pada tidak ada lembaga yang menyediakan bibit bagi usahatani kopi robusta. Baik kios saprodi, penangkar benih maupun pemerintah tidak berfungsi sebagai penyedia bibit bagi usahatani kopi robusta. Hal ini disebabkan oleh lemahnya subsistem on farm yang menggunakan bibit dari anakan yang tumbuh disekitar tanaman tua.

Bibit sebagai komponen subsistem hulu, mutlak diperlukan terlepas dari penyediaannya yang dilakukan sendiri ataupun harus disediakan oleh pengusaha input pertanian lainnya. Keterkaitan antara subsistem hulu dengan onfarm dapat dilihat dari usaha petani dalam memenuhi kebutuhannya untuk memulai usaha berkebun yaitu dalam pengadaan bibit, pupuk dan alat-alat mesin pertanian. Berdasarkan hasil survey dari 86 orang petani, diketahui bahwa penggunaan bibit dilihat dari asalnya dapat dibedakan atas dua kategori. Pertama bibit yang berasal dari kebun sendiri dan dari pedagang bibit. Petani responden menggunakan bibit yang sudah diusahakan sejak zaman penjajahan Belanda pada awal usahatani, dan untuk penyisipan tanaman yang tua dan mati, $100 \%$ petani menggunakan bibit yang tumbuh disekitar kebun mereka, tanpa melakukan proses pembibitan maupun pembelian bibit..

Menurut Hulupi (2008) melalui brosur yang dikeluarkan oleh Pusat Penelitian Kopi dan Kakao Indonesia (PPKKI), proses pembibitan kopi ada dua macam yaitu: Pertama pembibitan secara generatif dengan menggunakan benih atau biji, cara ini lebih mudah dan lebih singkat mencapai umur bibit siap tanam. Kedua pembibitan secara vegetatif atau klonal dengan melakukan stek atau penyambungan. Cara vegetatif merupakan cara yang lebih baik dilakukan karena memiliki keunggulan yaitu memiliki sifat genetik yang sama dengan tanaman tuanya, mutu hasilnya seragam, memanfaatkan dua sifat unggul batang atas dan bawahnya, dan memiliki umur mulai berbuah lebih awal.

Pada usahatani kopi robusta di Kabupaten Solok petani melalui bantuan penyuluhan dari Dinas Kehutanan dan Perkebunan Kabupaten Solok dapat melakukan proses pembibitan seperti yang dianjurkan oleh PPKKI tersebut diatas. Sehingga mutu bibit perbanyakan untuk peremajaan tanaman dapat terjaga kualitasnya sama dengan tanaman induknya. Adanya PPKKI sebagai lembaga penelitian menjadi peluang bagi pengembangan agribisnis kopi robusta di Kabupaten Solok karena keberadaan lembaga ini dapat 
membantu menyelesaikan permasalahan penggunaan bibit untuk penggantian tanaman pada sistem agribisnis kopi robusta di Kabupaten Solok.

Faktor produksi berikutnya adalah pupuk dan obat-obatan. Petani kopi robusta di Kabupaten Solok sebanyak 88,37 \% tidak melakukan pemupukan, dan 95,35\% tidak melakukan pengendalian hama dan penyakit.

Tabel 2. Jumlah Petani Yang Melakukan Pemupukan, Pengendalian Hama dan Penyakit, dan Pemangkasan

\begin{tabular}{llllll}
\hline \multirow{2}{*}{ o } & \multirow{2}{*}{ Kriteria } & \multicolumn{2}{c}{ Jumlah (Orang) } & \multicolumn{2}{l}{ Persentase (\%) } \\
\cline { 2 - 5 } & Ya & Tidak & Ya & Tidak \\
\hline \multirow{2}{*}{ Pemupukan } & 10 & 76 & 11,63 & 88,37 \\
& Pemangkasan & & 81 & 5,81 & 94,19 \\
Pengendalian Hama Penyakit & & 82 & 4,65 & 95,35 \\
\hline
\end{tabular}

Sumber : Data diolah, 2010

Pupuk dan obat-obatan dapat diperoleh petani melalui kios-kios yang terdapat kurang lebih $5 \mathrm{~km}$ dari lahan usahatani mereka. Adapun harga pupuk yang berlaku pada kios saprodi adalah Rp. 2.500,-/ kg untuk pupuk UREA, Rp. 2.500,-/ kg untuk pupuk SP36, Rp. 2.000,-/ kg untuk pupuk ZA, Rp. 3.000,untuk pupuk NPK, Rp. 1.500,- untuk pupuk organik. Harga yang berlaku disesuaikan dengan HET yang berlaku saat itu. Jauhnya jarak antara kios dengan lahan tempat usahatani membuat petani kesulitan untuk membawa pupuk ke lahan mereka. Selain itu kondisi jalan produksi yang masih terjal, licin dan berbatu membuat kendaraan sulit untuk melewatinya.

\section{Subsistem Usahatani}

Subsistem usahatani merupakan kegiatan budidaya mulai dari pengolahan tanah sampai pemanenan. Petani kopi robusta dalam melakukan usahatani kopi robusta belum mengusahakannya melalui budidaya yang baik. Persentase umur tanaman kopi robusta adalah 30,23 \% berumur 65 tahun untuk tanaman tua dan berumur 1-5 tahun sebanyak $50 \%$ untuk tanaman yang telah diremajakan. Rata-rata produktifitas kopi robusta adalah $629,031 \mathrm{Kg} / \mathrm{Ha}$. Menurut literatur produktifitas rata-rata untuk kopi robusta adalah 1.400 sampai $2.100 \mathrm{Kg} /$ ha $(A A K, 1995)$. Dengan demikian produktifitas kopi robusta Kab. Solok masih tergolong rendah.

Menurut Herman (2003), rendahnya mutu produksi kopi robusta terutama disebabkan oleh pengelolaan kebun, panen dan penanganan pasca panen yang kurang memadai karena hampir seluruhnya kopi robusta diproduksi oleh perkebunan rakyat. Disamping itu, pasar kopi masih menyerap seluruh produk kopi dan belum memberikan insentif harga yang memadai untuk kopi bermutu baik. Budidaya kopi sebenarnya sudah dilakukan oleh petani sejak jaman penjajahan, tetapi pengelolaannya masih tetap tradisional. Kesalahan yang paling fatal yang umum dilakukan petani 
adalah pada fase pemetikan dan penanganan pasca panen, sehingga menghasilkan kopi mutu rendah. Di hampir semua sentra produksi kopi, petani memetik buah kopi sebelum usia panen (petik hijau) dengan berbagai alasan seperti desakan kebutuhan hidup dan rawan pencurian.

\section{Subsistem Pemasaran}

Petani tidak memiliki posisi tawar yang kuat, karena kurangnya penguasaan teknologi ditingkat penciptaan, penguasaan teknik budidaya ditingkat proses produksi dan penguasaan jaringan informasi. Pemasaran masih tergantung pada mekanisme pasar. Petani hanya sebagai penerima harga. Harga yang berlaku untuk kopi robusta di Kab. Solok adalah sebagai berikut:

Tabel 3. Harga kopi robusta yang berlaku

\begin{tabular}{|c|c|c|c|}
\hline \multirow[t]{12}{*}{ o } & Kriteria & Pelaku Pemasaran & $\begin{array}{l}\text { Harga } \\
(\mathrm{Rp} / \mathrm{Kg})\end{array}$ \\
\hline & Beras Kopi & - Petani Kopi Robusta & \\
\hline & & $>$ Kec. Tigo Lurah & 9.500 \\
\hline & & $>$ Kecamatan Pantai Cermin & 10.00 \\
\hline & & $>$ Kecamatan X Koto Singkarak & 0 \\
\hline & & - Pedagang Pengumpul & 10.50 \\
\hline & & - Pedagang Antar Daerah & \\
\hline & & & 11.00 \\
\hline & & & 0 \\
\hline & & & 12.000 \\
\hline & Bubuk & - Industri Pengolahan Ke Konsumen & 34.00 \\
\hline & Kopi & & 0 \\
\hline
\end{tabular}

Rantai pemasaran Kopi Robusta di Kabupaten Solok dapat dilihat pada gambar 1. Petani kopi robusta memasarkan hasil usahataninya kepada pedagang pengumpul, kemudian pedagang pengumpun memasarkan kepada pedagang antar daerah (PAD) dan PAD memasarkan kepada Eksportir dan Industri RT pengolahan kopi. 


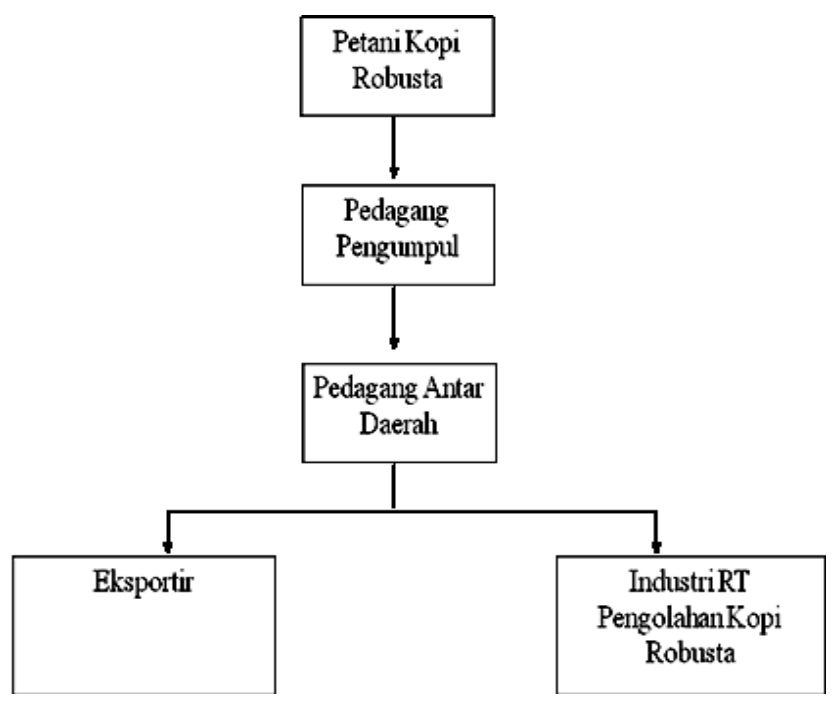

Gambar 1. Rantai pemasaran kopi robusta di Kabupaten Solok

Kemudian oleh eksportir dalam perdagangan internasional kopi dapat dijual dalam bentuk seperti gambar 2 dibawah ini.

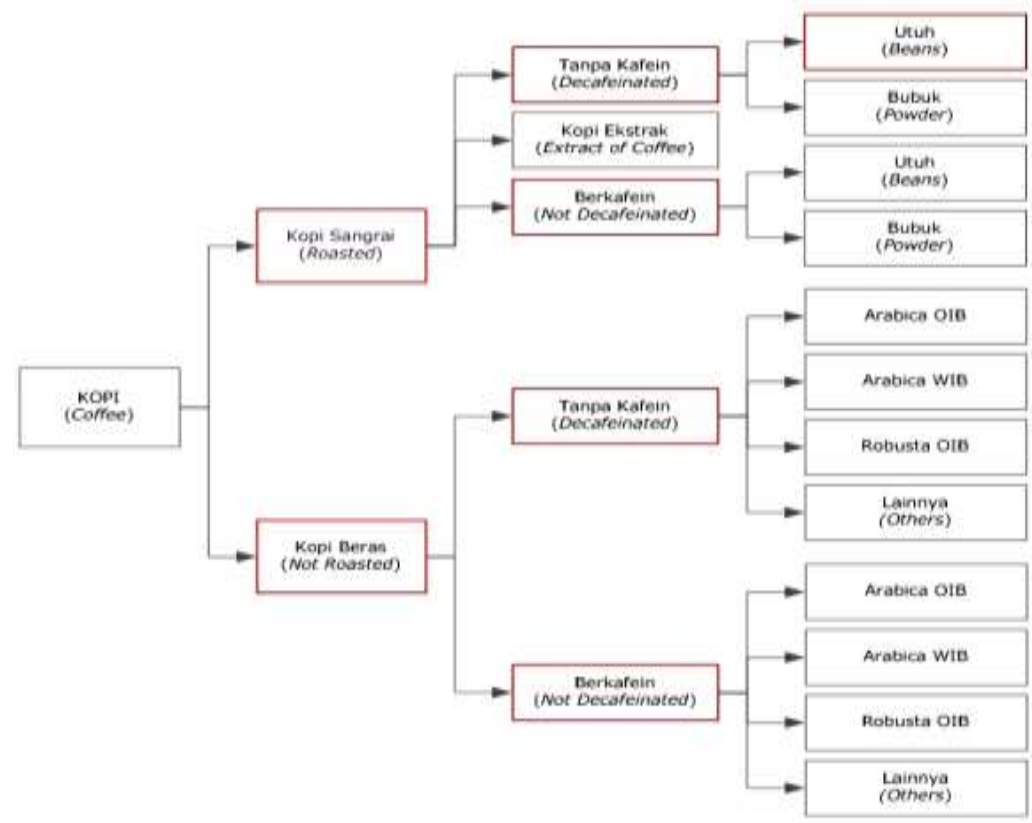

Gambar 2. Profil Komoditi Kopi dalam Perdagangan Internasional

Sumber : Bank Indonesia, Profil Komoditi Ekspor Indonesia (2010)

Dari gambar diatas dapat dilihat bahwa kopi robusta dijual dalam bentuk kopi beras, baik yang berkafein dan tanpa kafein. Adapun kualitas yang ditetapkan untuk kopi beras yang diperdagangkan sesuai dengan Standar Nasional Indonesia (SNI) adalah sebagai berikut (Tabel 4) 


\section{Tabel 4. Standar Mutu Untuk Produk Beras Kopi Robusta}

Kode HS : 090111300

Nama komoditi : Kopi Robusta OIB

Kode Standar Mutu : SNI.01-2907-1992-A

Tahun : 1992

Kriteria Uji :

\begin{tabular}{llll}
\hline No & \multicolumn{1}{c}{ Test Kriteria } & Satuan & Persyaratan \\
\hline & Kadar Kotoran (Ranting, Batu, Tanah Dll) & $\%(w / w)$ & Maks 0.5 \\
& Serangga Hidup & - & Bebas \\
& Biji Berbau Busuk Dan Berbau Kapang & - & Negative \\
& Biji Tidak Lolos Ayakan 3 Mm X 3 Mm (8 & $\%(w / w)$ & maks lolos 1 \\
Mesh) & & \\
Biji Ukuran Besar, Tidak Lolos Ayakan 3.5 & $\%(w / w)$ & maks lolos 1 \\
Mesh & $\%(b / b)$ & Maks.13 \\
\hline \multicolumn{1}{c}{ Kadar Air } & & \\
\hline
\end{tabular}

Sumber : Bank Indonesia, 2010

\section{Subsistem Pengolahan Pasca Panen}

Kegiatan yang dilakukan pada pasca panen oleh petani kopi robusta adalah pengolahan buah kopi menjadi beras kopi dengan cara pengolahan kering dengan dijemur dibawah sinar matahari. Belum ada proses fermentasi yang dilakukan untuk pengolahan beras kopi. Dalam melakukan panen petani tidak memisahkan antara buah masak dan belum masak, sehingga beras kopi yang dihasilkan tidak dapat dibedakan antara mutu yang baik dan yang kurang baik. Untuk kualitas beras kopi yang lebih baik, maka sebaiknya dilakukan pemisahan antara buah masak dengan setengah masak, atau muda, dan dilakukan proses fermentasi sebelum dilakukan pengolahan kering Kualitas komoditi pertanian dan perkebunan ditentukan oleh budidayanya, penangangan pasca panen dan pengolahan. Pengolahan biji kopi dapat dilakukan dengan dua cara, yaitu cara basah (wet process) dan cara kering (dry process). Pengolahan cara basah memerlukan proses yang cukup memakan waktu dan tenaga, antara lain dengan melakukan proses fermentasi biji, sehingga hanya dilakukan di perkebunan besar. Sedangkan cara kering untuk perkebunan rakyat, umumnya dilakukan oleh petani karena prosesnya yang lebih sederhana dari pada proses basah (AAK, 1995).

Seperti yang telah dijelaskan sebelumnya bahwa dalam proses pemanenan petani tidak melakukan pemisahan antara buah kopi yang sudah masak sempurna dengan yang belum masak. Begitu juga dengan proses penanganan pasca panen, petani tidak melakukan penyortiran terhadap buah kopi muda yang ikut terbawa pada saat proses pemanenan, mereka langsung melakukan penggilingan untuk memisahkan kulit buah dengan biji kopi. Ini menyebabkan 
kualitas beras kopi kering yang dihasilkan tidak sempurna karena tercampur dengan kopi yang masih muda. Dalam melakukan proses pengeringan (penjemuran) petani menggunakan cara konvensional dengan menjemurnya dibawah sinar matahari. Pada kegiatan ini petani juga tidak memperhatikan kebersihan dari tempat penjemuran, mereka menggunakan jalan desa sebagai tempat penjemuran tanpa menggunakan alas berupa plastik atau terpal.

\section{Subsistem Jasa Penunjang}

Jalanan produksi yang menghubungkan kebun dengan jalan utama masih dalam kondisi jalan batu yang diperkeras dan dalam kondisi yang rusak parah Untuk perhubungan pada jalan utama yang menghubungkan jalan kecamatan dan jalan kabupaten berada dalam kondisi baik, dan sarana transportasi tersedia dengan baik.

Akses terhadap lembaga keuangan, $100 \%$ petani menyatakan menggunakan modal sendiri dalam mengusahakan usahatani kopi robusta mereka. Petani tidak memanfaatkan sarana lembaga keuangan yang tersedia di kecamatan yaitu berupa Bank BRI, Bank Nagari ataupun LPN.

Untuk kegiatan Penyuluhan dan Layanan Informasi Agribisnis, lembaga yang berwenang dalam melakukan penyuluhan adalah Dinas Kehutanan dan Perkebunan kab. Solok, dan Dinas KUKM dan Perindag Kab. Solok. Berdasarkan hasil wawancara diperoleh keterangan bahwa penyuluhan yang dilakukan oleh kedua instansi masih belum maksimal membantu dalam memberikan informasi mengenai agribisnis kopi robusta.

Kegiatan penelitian dan pengembangan dilakukan melalui BPTP sukarami dan Universitas Muhammad Yamin Solok. Pemerintah Kab. Solok telah menetapkan tiga pilar pembangunan ekonomi kerakyatan yaitu Peningkatan produktivitas pelaku usaha ekonomi kerakyatan sebagai bentuk dukungan kebijakan pemerintah terhadap ekonomi rakyat. Agribisnis kopi robusta termasuk kedalam usaha yang dijalankan dalam skala ekonomi kerakyatan, maka kebijakan pemerintah tersebut dapat mendukung pengembangannya.

\section{Analisa Sistem Agribisnis Kopi Robusta di Kabupaten Solok}

Suatu sistem merupakan keseluruhan interaksi antara unsur dari sebuah objek dalam batas lingkungan tertentu yang bekerja mencapai tujuan. Yang dimaksud dengan unsur adalah benda, baik konkrit atau abstrak yang menyusun objek sistem atau dapat juga disebut dengan bagian dari sistem atau sub-sistem. Pengertian dari keseluruhan adalah lebih dari sekedar penjumlahan atau susunan, yaitu terletak pada kekuatan yang dihasilkan oleh keseluruhan itu jauh lebih besar dari suatu penjumlahan atau susunan. Misalnya dalam suatu organisasi bisnis yang dimaksud dengan sistem adalah keseluruhan interaksi dari bagian produksi, pemasaran, keuangan dan personalia melalui jaringan kerjasama tim. Kekuatanya jauh lebih besar dibandingkan 
dengan keseluruhan interaksi bagian produksi, pemasaran, keuangan dan personalia yang berjalan sendiri-sendiri (Amminullah dan Muhammadi, 2001).

Agribisnis kopi robusta merupakan sebuah sistem yang memiliki interaksi antar subsistem, yaitu subsistem hulu, subsistem usahatani, subsistem hilir (pemasaran dan pengolahan hasil), dan subsistem penunjang. Keseluruhan subsistem diharapkan dapat saling berinteraksi dalam rangkaian kerja yang dapat menghasilkan kekuatan yang bertujuan untuk meningkatkan pertumbuhan ekonomi wilayah melalui peningkatan kesejahteraan pelaku agribisnis tersebut. Namun kondisi pada masing-masing subsistem dalam agribisnis kopi robusta seperti yang telah dijelaskan pada bagian sebelumnya, masing-masing subsistem bekerja sendiri-sendiri sesuai dengan bidangnya, sehingga kekuatan yang diharapkan tidak dapat terbentuk.

Sedangkan yang dimaksud dengan interaksi adalah pengikat atau penghubung antar unsur yang memberi bentuk/struktur kepada objek, membedakan dengan objek lainnya dan mempengaruhi prilaku dari objek. Unjuk kerja dari sistem ditentukan oleh fungsi unsur. Gangguan salah satu unsur mempengaruhi unsur lainnya sehingga akan mempengaruhi unjuk kerja sistem secara keseluruhan (Amminullah dan Muhammadi, 2001).

\section{Analisa Potensi Agribisnis Perkebunan Rakyat Kopi Robusta di Kab. Solok}

Agribisnis kopi robusta merupakan sebuah sistem yang memiliki interaksi antar subsistem, yaitu subsistem hulu, subsistem usahatani, subsistem pemasaran, subsistem pengolahan hasil dan subsistem penunjang. Keseluruhan subistem diharapkan dapat berinteraksi dalam rangkaian kerja yang dapat menghasilkan kekuatan. Namun dalam agribisnis kopi robusta setiap subsistem belum saling berinteraksi dengan maksimal sehingga sistem ini menjadi lemah dalam menghadapi pengaruh dari lingkungan diluar sistem agribisnis kopi robusta tersebut.

Agribisnis kopi robusta di Kabupaten Solok yang selalu berinteraksi dengan lingkungan diluarnya baik pesaing, konsumen, pasar domestik, regional dan global sehingga sistem agribisnis kopi robusta dapat dikategorikan sebagai sistem terbuka, karena pengaruh lingkungan diluar sistem agribisnis kopi robusta sangat besar terhadap perkembangannya. Kekuatan yang terdapat didalam sistem diharapkan dapat mengatasi pengaruh dari lingkungan diluar sistem. Namun sistem agribisnis kopi robusta di Kabupaten Solok belum berinteraksi dengan baik sehingga sistem ini menjadi lemah dalam menghadapi pengaruh dari lingkungan yang ada di luar sistem agribisnis kopi robusta. Misalnya saja dalam menghadapi turunnya harga jual beras kopi robusta yang diperdagangkan akibat turunnya jumlah permintaan dari pasar global, tidak ada tindakan yang dapat diberikan oleh sistem karena subsistem yang terdapat dalam sistem agribisnis kopi robusta bekerja sendiri-sendiri sesuai dengan wilayah kerjanya masing-masing. 
Selain tidak adanya jaringan kerjasama antar subsitem, tidak bekerjanya salah satu subsistem dalam sistem agribisnis kopi robusta juga dapat mengakibatkan sistem ini menjadi lemah. Misalnya pada subsistem usahatani, kurang maksimalnya peranan penyuluh pertanian dalam membina petani mengakibatkan produktivitas kopi robusta menjadi rendah.

Saat ini kopi robusta yang dihasilkan oleh Kabupaten Solok, belum mampu menciptakan keunggulan bersaing dengan produk yang sama yang dihasilkan oleh daerah lainnya, baik dari segi produktivitas maupun dari kualitas yang dimiliki, hal ini disebabkan karena pengelolaan agribisnis kopi robusta yang masih belum terdapat keterkaitan antar subsistem. Kemudian Gambaran sistem agribisnisnya dapat dilihat pada lampiran 1.

Masing-masing subsistem merupakan suatu kesatuan yang tidak dapat dipisahkan fungsinya satu sama lain, karena menurut Firdaus dalam bukunya Manajemen Agribisnis (2008), berdasarkan kepada pengalaman masa lalu bahwa pembangunan pada subsistem on farm (usahatani) yang tidak disertai dengan pengembangan subsistem yang lain tidak mampu mendayagunakan keunggulan komparatif menjadi keunggulan bersaing (kompetitif). Dimana menurut Sudaryanto dan Simatupang (1993) cit Daryanto (2009), keunggulan komparatif adalah kelayakan ekonomi dan keunggulan kompetitif adalah kelayakan finansial dari suatu aktifitas. Maka jika subsistem dalam agribisnis kopi robusta dilakukan secara terpisah keunggulan bersaing yang diharapkan dalam sistem agribisnis tersebut tidak dapat tercapai.

Kopi robusta adalah komoditas unggulan Kabupaten Solok yang belum mampu bersaing dengan komoditas yang sama dari daerah lain karena kualitas yang dihasilkan tidak mampu memberikan daya saing yang diharapkan, karena pengelolaan pada masing-masing subsistem belum sepenuhnya mendukung untuk memperoleh keunggulan bersaing tersebut. Agribisnis kopi robusta dapat memberikan keuntungan ekonomi bagi daerah namun belum mampu memberikan keuntungan secara finansial. Karena keunggulan komparatif dapat dicapai pada saat kondisi ekonomi tidak mengalami distorsi. Distorsi yang dimaksud diantaranya adalah kebijakan pemerintah baik bersifat langsung (tarif) maupun yang tidak langsung (regulasi), dan distorsi pasar karena adanya ketidaksempurnaan pasar. Sedangkan keunggulan kompetitif diperoleh pada saat keadaan ekonomi aktual (Simatupang (1991) cit Daryanto, 2009).

Peranan pemerintah dalam mengembangkan agribisnis kopi robusta diharapkan dapat menjangkau seluruh subsistem yang ada, sehingga setiap subsistem dapat bersinergi dengan baik menuju berkembangnya agribisnis kopi robusta di Kabupaten Solok. Pengembangan agribisnis kopi robusta akan mampu meningkatkan kesejahteraan masyarakat yang terkait dalam pengelolaan agribisnis kopi robusta, sehingga pada akhirnya diharapkan dapat meningkatkan pertumbuhan ekonomi dan pembangunan daerah Kabupaten 
Solok. Hal ini sesuai dengan visi Kabupaten Solok untuk meningkatkan kesejahteraan masyarakat dengan membangun ekonomi kerakyatan. Menurut Daryanto (2009), terjadinya integrasi ekonomi yang kuat, menyeluruh dan berkelanjutan diantara semua sektor ekonomi menjadi kunci keberhasilan pembangunan ekonomi suatu daerah. Dengan demikian, agribisnis perkebunan rakyat kopi robusta di Kabupaten Solok masih memiliki potensi untuk dilakukan pengelolaan dan pengembangannya.

\section{SIMPULAN DAN SARAN}

\section{Simpulan}

Kesimpulan dari penellitian ini adalah:

1. Masing-masing subsistem dalam agribisnis kopi robusta, masih bekerja sendiri-sendiri, sehingga belum terdapat saling interaksi dalam rangkaian kerja yang dapat menghasilkan kekuatan yang bertujuan untuk meningkatkan pertumbuhan ekonomi wilayah.

2. Agribisnis kopi robusta dapat memberikan keuntungan ekonomi bagi daerah namun belum mampu memberikan keuntungan secara finansial. Pengembangan agribisnis kopi robusta akan mampu meningkatkan kesejahteraan masyarakat yang terkait dalam pengelolaan agribisnis kopi robusta serta dapat meningkatkan pertumbuhan ekonomi dan pembangunan daerah Kabupaten Solok. Dengan demikian, agribisnis perkebunan rakyat kopi robusta di Kabupaten Solok masih memiliki potensi untuk dilakukan pengelolaan dan pengembangannya.

\section{Saran} lah :

Adapun saran yang dapat direkomendasikan dalam penelitian ini ada-

1. Peranan pemerintah dalam mengembangkan agribisnis kopi robusta diharapkan dapat menjangkau seluruh subsistem yang ada, sehingga setiap subsistem dapat bersinergi dengan baik menuju berkembangnya agribisnis kopi robusta di Kabupaten Solok

2. Untuk dapat mengembangkan agribisnis kopi robusta di Kab. Solok, maka disarankan seluruh unsur yang terdapat dalam sistem agribisnis dapat meningkatkan kualitas yang dihasilkan dengan pengelolaan yang sepenuhnya mendukung untuk memperoleh keunggulan bersaing.

\section{DAFTAR PUSTAKA}

AAK. 1995. Budidaya Tanaman Kopi. Jakarta : Kanisus 
Admaizon, 2004. Agribisnis Kopi Arabika Kabupaten Solok dengan Pendekatan Kimbun. Solok : Warta Rimbun edisi 2/2004

Ahmad, 2006. Analisa Pengaruh Program Pemberdayaan Ekonomi Kerakyatan Sektor Industri Terhadap Perkembangan Usaha Kecil Di Kota Pekanbaru Propinsi Riau. Tesis Pascasarjana Universitas Andalas.

Aminullah, Erman dan Muhammadi. 2001. Sistem dan Berfikir Sistemik. Jakarta: UMJ Press

Pemerintah Daerah Kabupaten Solok. 2008. Rencana Induk Pembangunan Pertanian Kabupaten Solok. Sukarami : Bappeda Kabupaten Solok

Hulupi, Retno. 2008. Perbanyakan Klonal Kopi. Jember. Pusat Penelitian Kopi dan Kakao Indonesia

Retnandari. 1991. Kopi : Kajian Sosial Ekonomi. Jogjakarta. Aditya Meida.

Susila, Wayan R. dan Bambang Drajat, 2009. Agribisnis Perkebunan Memasuki Abad 21 beberapa Agenda Penting. http://www.ejournal.unud.ac.id (20 Januari 2009)

Sutriono, 2009. Strategi Peningkatan Daya Saing Agribisnis Kopi Robusta dengan Model Daya Saing Tree Five. Pusat Analisis Sosial Ekonomi Kebijakan Pertanian Badan Penelitian dan Pengembangan Pertanian Departemen Pertanian

\section{Lampiran 1. Gambar Sistem Agribisnis Kopi Robusta di Kabupaten Solok}

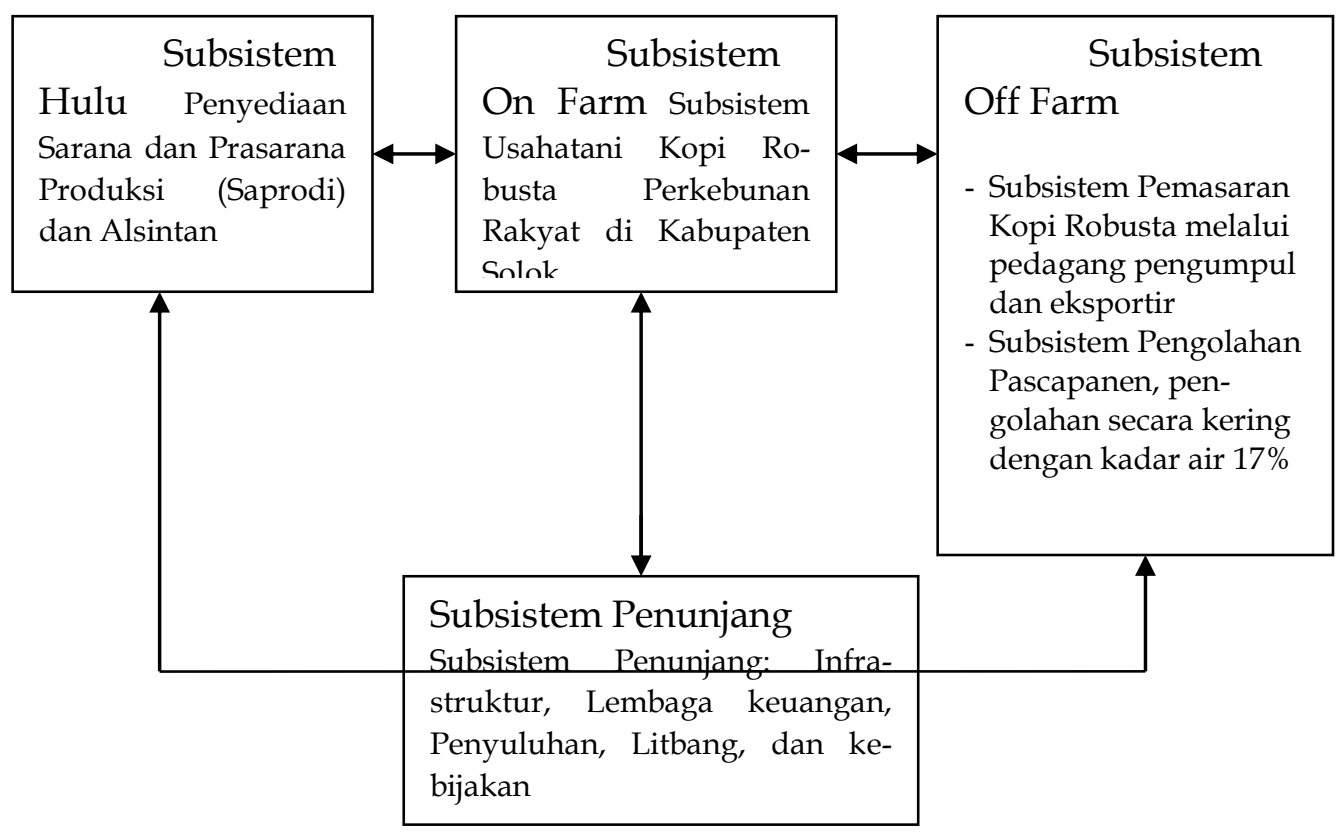

Rika HAriance, Rudi Febriamansyah, Faidil Tanjung. Agribisnis Perkebu... 25 